\title{
A Forgotten Roman Mausoleum In Darende, Malatya: The Architectural Features and Conservation Issues of the Ozan Monument
}

\author{
Malatya Darende'de Unutulmuş Bir Roma Mozolesi: Ozan Anıtı, Mimari Özellikleri ve \\ Koruma Sorunları
}

\author{
Mustafa Kaan Sağ ${ }^{\star}$, Kemal Kutgün Eyüpgiller* ${ }^{\star *}$
}

\begin{abstract}
The single-chamber temple tomb in Darende, Malatya, referred to today as the Ozan Monument, is a continuation of the mausoleum tradition that began to be popular in Anatolia in the Hellenistic Period. This type of tomb was built monumentally in the form of a Greek temple in order to deify, glorify and elevate the dead to the heroic level and also bestow upon the dead fame and honor. It is one of the outstanding examples of the Roman mausolea which have survived to the present day in good condition. Since there is no inscription on this monument, it is not possible to surmise the name of the dead or its builder. Its construction techniques, style and the features of its decorative components indicate that it was built roughly in the $2^{\text {nd }}$ century AD. Overall on the monument there is some structural damage and surface deterioration on the stones. The biggest problem of the monument is the ruptures in the corner stones of the facades and the missing stones at the base and the foundation. Nonetheless, the monument has survived to today and has maintained its physical integrity to a great extent. The restitution drawings were prepared by analyzing the marks remaining on the building and similar temple tombs of the same period. The restoration project was substantially based on the restitution and the necessary interventions were determined to support the building in the best way possible and carry it to the future.
\end{abstract}

\section{Keywords}

Roman Architecture, Malatya, Mausoleum, Conservation, The Ozan Monument

\section{Öz}

Günümüzde Ozan Anıtı olarak adlandırılan Malatya, Darende'deki tek hacimli anıt mezar, Helenistik dönemden itibaren Anadolu'da yaygınlaşmaya başlayan Yunan tapınağı formundaki mozole geleneğinin bir devamıdır. Ölüyü tanrılaştırmak, yüceltmek, kahramanlık seviyesine çıkarmak, ölümsüzleştirmek, şan ve şeref sahibi yapmak bu tip mezarların yapılış amacını ortaya koymaktadır. Yapı, Roma dönemi anıtsal mezar yapılarının günümüze en iyi durumda ulaşmış, seçkin örneklerinden biridir. Bu özelliğine karşın gözden kaçırılmış, tarihi ve mimari özellikleri üzerine herhangi bir çalışma yapılmamıştır. Üzerinde yazıt bulunmadığı için yapının kimin için yaptırıldığı ya da banisi hakkında kanıya varmak olası değildir. Yapım tekniği, üslubu ve dekoratif öğelerin niteliği göz önünde tutularak anıtın kabaca M.S. 2. yüzyıla tarihlendiği görülmektedir. Yapının

* Correspondence to: Mustafa Kaan Sağ (Asst. Prof. Dr.), Istanbul University, Faculty of Architecture, Department of Interior Architecture, Istanbul, Turkey. E-mail: kaansag@istanbul.edu.tr ORCID: 0000-0001-7463-811X

** Kemal Kutgün Eyüpgiller (Prof. Dr.), Istanbul University, Faculty of Architecture, Department of Architecture, Istanbul, Turkey. E-mail: kkutgun.eyupgiller@istanbul.edu.tr ORCID: 0000-0001-9328-7829

To cite this article: Sag, Mustafa Kaan \& Eyupgiller, Kemal Kutgun. "A Forgotten Roman Mausoleum In Darende, Malatya: The Architectural Features and Conservation Issues of the Ozan Monument." Art-Sanat, 14(2020): 385-412. https://doi.org/10.26650/artsanat.2020.14.0015 
genelinde taşlarda yüzey kaybı bulunmakta ve yer yer strüktürel hasarlar görülmektedir. En büyük problemi cephelerde köşe taşlarında görülen kopmalar ile yapı kaide ve temelindeki eksik taşlardır. Yapının çevresinde zemin kotu düşürülmüş ve yapının temeli ortaya çıkmıştır. Bu eksiklikler nedeniyle duvarların taşıyıcılık özelliği zayıflamıştır. Üst kaplama büyük ölçüde yok olmuş ve anıtın üst örtüsü düz çatı hâlini almıştır. Buna rağmen büyük ölçüde fiziksel bütünlüğünü koruyarak günümüze ulaşan anıtın restitüsyon çizimleri, yapı üzerindeki mevcut izler ve benzer dönem yapıları incelenerek hazırlanmıştır. Restorasyon projesi ise büyük ölçüde restitüsyona dayalı olarak hazırlanmış; yapının en doğru şekilde ayakta tutulabilmesi ve geleceğe aktarılabilmesi için gerekli müdahaleler belirlenmiştir.

Anahtar Kelimeler

Roma Mimarisi, Malatya, Mozole, Koruma, Ozan Anıtı

\section{Genisletilmis $\ddot{O}_{z, e t}$}

Varlıklı Romalılar, Erken İmparatorluk Dönemi’nde kendileri, aileleri ve köleleri için mezar yapıları yaptırmıştır. Gösterişli definler için urnalar (kül kapları) kullanılmış ya da kabartmalı mezar stelleri yapılmıştır. Et yiyen manasına gelen sarkofaj (lahit) ancak az sayıda kişinin yaptırabildiği mezarlarken lahitlerin anıtsal boyuttaki versiyonları olan mozoleler çok özel kişiler için nadiren inşa edilmiştir. Günümüzde Ozan Anıtı olarak adlandırılan tek hacimli anıt mezar, Helenistik dönemden itibaren Anadolu'da yaygınlaşmaya başlayan Yunan tapınağı formundaki mozole geleneğinin bir devamı olarak karşımıza çıkmaktadır. "Ölüyü tanrılaştırmak, yüceltmek, kahramanlık seviyesine çıkarmak, ölümsüzleştirmek, şan ve şeref sahibi yapmak" bu tip mezarların yapılış amaçlarından bazılarıdır.

Ozan anıt1, günümüzde Malatya İli, Darende İlçesi, Ozan Köyü’nde 154 ada, 20 parselde, köyün çeperinde, kayısı bahçeleri içerisinde yer almaktadır. Yapının üzerinde yazıt bulunmadığı gibi, yapı hakkında kaynaklarda herhangi bir bilgiye de rastlanmamıştır. Dolayısıyla yapının inşa tarihi ve banisi hakkında kesin bir kanıya varmak olası değildir. Yapım tekniği, üslubu ve dekoratif öğelerin niteliği göz önünde tutularak anıtın Roma İmparatorluk dönemine ait olduğu ve kabaca M.S. 2. yüzy1la tarihlendiği görülmektedir. Nitekim başlangıçta basit çadır kamplarına sahip olan Samosata, Zeugma ve Dura Europos'un yanı sıra Fırat Nehir hattının önemli geçitlerinden biri olan Melitene, M.S. 2. yüzyıldan itibaren Roma İmparatorluğu tarafindan Part İmparatorluğu'na karşı bir lejyon şehri hâline getirilmiştir.

Yunan tapınağı formundaki mozole geleneğinin ilk örneklerinden biri, Ksantos'taki (Xanthos) Nereidler Anıtı'dır (M.Ö. 400-380). Nereidler Anıtı, dikdörtgen ve yüksek bir podyum üzerinde İyon düzeninde bir tapınak formuna sahiptir. Benzer şekilde Ozan Anıtı da İyon düzeninde bir tapınak formunda tasarlanmıştır. Ancak Roma tapınaklarında da yaygın olarak görülen yüksek podyum kullanımının aksine Ozan Anıtı'nda podyum kullanılmamıştır. Yapının yerden yüksekliği yaklaşık 6,5 metredir. Batı cephesinde yer alan giriş kapısı, kapı üzerindeki tepe penceresi ve doğu cephesindeki tepe penceresi dışında tüm cepheleri özdeştir. Cephelerde bir yapı kaidesi ya da stilobat üzerinde yükselen dört adet İyon sütunu ve üstlerinde yine İyon düzeninde bir saçaklık yer almaktadır. Bu saçaklık üç fasyalı bir arşitrav, düz bir friz ve kornişten oluşmaktadır. 
Cephedeki sütunlardan köşede bulunanlar 3/4 sütun, ortada bulunanlar ise yarım sütundur. Cephelerine taşıyıcı özelliği olmayan yarım sütun yerleştirilmiş bu tip tapınaklar, Antik Yunan döneminden itibaren kullanılmış ve pseudoperipteros olarak adlandırılmıştır. Yalancı peripteros anlamına gelen bu tipte, tapınağı çevreleyen yarım sütunlar yapının peripteros olduğu, yani dört tarafi serbest sütunla çevrilmiş olduğu izlenimini vermektedir. Sütunların arasında her cephede simetrik olarak yerleştirilmiş üç adet küçük niş bulunmaktadır. Bu nişler yerden yaklaşık 4 metre yükseklikte ve saçaklığa yakın bir biçimde konumlandırılmıştır. Nişlerin çerçevelerine iki adet sütunla taşınmış kemer formu verilirken nişlerin hemen altında aşağ doğru sarkmış kalın girland rölyefleri yerleştirilmiştir. Bu nişlerden batı ve doğu cephelerinde ortada bulunanlar pencere fonksiyonu görecek şekilde açılmış ve çerçeveleri dikdörtgen formunda tasarlanmıştır.

Girlandlar (ask1-çelenkler) Roma dönemi lahitlerinde insan ve hayvan figürlerinin yanı sıra en sık kullanılan süslerdir. Bu süslerin anlamını açıklayan yazılı kaynaklar bulunmamaktadır. Söz konusu çelenkler çoğunlukla çiçek, meyve, defne, meşe, sarmaşık yaprağ 1 ve çam kozalağı gibi bitkisel elemanların bir araya getirilerek kurdeleler ile sarılması sonucu oluşturulmuştur. Girlandlı süslemelerin Roma dönemindeki ilk örnekleri M.S. 1. ve 2. yüzyılda üretilen mezar sunaklarıyla kül urnalarında görülmektedir. Girlandlı lahitler ise 2. yüzyılın başlarında ortaya çıkmış, ortalarında yaygınlaşmış ve aynı yüzyıl sonlarında yaygın kullanımını kaybetmeye başlamıştır. Roma İmparatorluğu Kapadokya Eyaleti sınırları içerisinde bulunan ve bir kısmı girlandlı olan lahitler de çoğunlukla 2. yüzyılın sonlarına tarihlenmektedir.

Aslında girland motifi, Roma döneminden önce kare veya daire biçimli bir taban üstünde yükselen sunakların süslenmesinde kullanılmıştır. Helenistik dönem girlandları, sadece yapraklardan yapılmış olup incedirler, ortalarında kalınlaşmazlar ve aşağıya doğru sarkmazlar. Roma İmparatorluk dönemi girlandları ise ortalarında kalınlaşır ve aşağıya doğru sarkarlar. Bu bilgiler ışığında Ozan Anıtı'nda karşılaşılan girlandların Roma Dönemi’ne ait olduğu ve kabaca M.S. 2. yüzyılda yapıldığı anlaşılmaktadır. Ayrıca girland ve üzerlerindeki nişler, anıt mezarın yapıldığı kişiye ithafen dönem dönem adak adandığını ve bu adakların nişlere yerleştirildiğini düşündürmektedir.

Yapının genelinde taşlarda yüzey kaybı bulunmakta, yer yer strüktürel hasarlar da görülmektedir. Yapının en büyük problemi cephelerde köşe taşlarında görülen kopmalar ile yapı kaide ve temelindeki eksik taşlardır. Yapının çevresinde zemin kotu düşürülmüş, anıtın temelleri açığa çıkmıştır. Bu eksiklikler nedeniyle duvarların taş1yıcılık özelliği zayıflamış, beden duvarından ayrılmalar meydana gelmiştir. Yapının üst örtüsündeki eksiklikler de yapıyı olumsuz etkilemektedir. Kimi yerde arşitrav ve korniş arası bölge yok olmuştur. Üst örtüdeki bitki oluşumu da yapıda dış kütlede görülen önemli bozulmalardandır. Üst kaplama büyük ölçüde yok olmuş ve anıtın üst örtüsü düz çatı hâlini almıştır. 
İç mekânın genelinde yüzey kirliliği hâkimdir. Yapının güney duvarında kesme taş yüzey sonradan oyularak mihrap benzeri bir niş oluşturulmuştur. Kesme taş yüzeylerde kısmi derin oyuklar bulunmakta, taşların bir kısmında da yüzeysel aşınma görülmektedir. Tavan yüzeyinde tonoz üzengi/başlangıç kotundan itibaren yoğun bir karbon tabakası/yüzey kirliliği ile bazı bölümlerde nem ve buna bağlı tuzlanma görülmektedir. İç mekân döşeme kaplaması kısmen yok olmuş, kısmen toprak dolgunun altında kalmıştır.

Ozan Mezar Anıt1, büyük ölçüde fiziksel bütünlüğünü koruyarak günümüze ulaşmıştır. Restitüsyon çizimleri, yapı üzerindeki mevcut izler ve benzer dönem yapıları incelenerek hazırlanmıştır. 20. yüzyılın başlarında Anadolu'yu gezerek pek çok tarihi eseri tespit eden Gertrude Bell'in Anadolu'da fotoğrafladığı binalar arasında Ozan Anıtı da yer almaktadır. Bu fotoğraflardan anlaşıldığı üzere, yapıdaki bozulmaların büyük bir bölümü fotoğrafların çekildiği tarihte de mevcuttur. Yapının kare formu ve birbirini tekrar eden cephelerden oluşması, eksik yapısal detay ve motiflerin tamamlanmasında kolaylık sağlamıştır. Cephelerde görülen büyük boyutlu detay ve malzeme eksiklikleri, yapı üzerindeki diğer elemanlar incelenerek tamamlanmıştır. Anıtın restorasyon projesi büyük ölçüde restitüsyona dayalı olarak hazırlanmış; yapının en doğru şekilde ayakta tutulabilmesi ve geleceğe aktarılabilmesi için gerekli müdahaleler belirlenmiştir.

Ozan Mezar Anıtı, Roma dönemi anıtsal mezar yapılarının günümüze iyi durumda ulaşmış seçkin örneklerinden biridir. Bu özelliğine karşın yapı gözden kaçırılmış, tarihi ve mimari özellikleri üzerine herhangi bir çalışma yakın geçmişe dek yapılmadığı gibi onarımı da gündeme gelmemiştir. Yapıya ait rölöve, restitüsyon ve restorasyon projeleri, ilgili Koruma Bölge Kurulunca onaylanmış olup, restorasyon projesinin uygulama aşamasına geçilmesi beklenmektedir. Anadolu'nun zengin kültürel miras1nın bu denli önemli bir örneğinin özenli bir restorasyon sürecinin ardından bölgenin kültür turizmine önemli bir katkı sağlayacağı düşünülmektedir. 


\section{Introduction}

During the Early Imperial Period the affluent Romans commissioned tombs for themselves, their family members and slaves. For elaborate funerals they used either urns, in other words vases, for storing the ashes of cremated bodies or embossed funerary steles. While sarcophagi (meaning "carnivorous" and called "lahit" in Turkish) were tombs only a few people could afford, the monumental tombs in the form a Greek temple, known as mausolea, were built very rarely and only for special people. ${ }^{1}$ The single-chamber temple tomb referred today as the Ozan Monument is a continuation of the mausoleum ${ }^{2}$ tradition that began to be popular in Anatolia in the Hellenistic Period. This type of tomb was built monumentally in the form of a Greek temple in order to deify, glorify and elevate the dead to the heroic level and also bestow upon the dead fame and honor. ${ }^{3}$ All Anatolian, Greek and Persian customs resulted in the emergence of so called temple tombs, the predecessors of which can be found within previous monuments of the Karian and the Lykian dynasties. Through these sacred monumental tombs, also called Heroon, native dynasts tried to legitimize their power basing on divinized ancestors and family members. ${ }^{4}$

\section{Location and History}

Today, the Ozan Monument is located in the Ozan village in Darende, Malatya ${ }^{5}(\mathrm{~F}$. 1), on block 154, plot 20 in the outskirts of the village, inside the apricot gardens (F. 2, F. 3, F. 4, F. 5, F. 6). As Darende lies $110 \mathrm{~km}$. to the northwest of the city centre, the Ozan village is located in the middle of Darende and Malatya centre, $40 \mathrm{~km}$. away from Darende. ${ }^{6}$ There is no inscription on this monumental building and no epigraphic information is available in former sources. Therefore, it is not possible to surmise the construction date or the name of its builder. Taking into consideration its construction

1 Guntram Koch, Roma İmparatorluk Dönemi Lahitleri, trans. Z. Zühre İlkgelen (İstanbul: Arkeoloji ve Sanat Yayınları, 2001), 1.

2 For more information on mausolea see Ian Jenkins, "The Mausolea of Halicarnassus", Bulletin of the Institute of Classical Studies 104 (2010), 121-135.

3 Jocelyn J.M.C. Toynbee, Death and Burial in the Roman World (London: Thames and Hudson, 1996), 130.

4 Lucia Novakova, "Tombs, Images and Identities in Ancient Anatolia", ILIRIA International Review 7/2 (2017), 13; Lucia Novakova, "Closer to Heaven: The Tradition of Above Ground Burials in Western Anatolia”, EY $\triangle A I M \Omega N$ : Studies In Honour of Jan Bouzek, ed. P. Pavúk, V. Klontza-Jaklová and A. Harding (Prague: Charles University Faculty of Arts, 2018), 179-200.

5 The modern town of Malatya was founded in 1838 near the sites of two earlier settlements: the Hittite city of Milid, on the site of the present-day Arslantepe, $6 \mathrm{~km}$ north and its successor, the Roman and medieval city of Melitene, now called Eski (Old) Malatya, $10 \mathrm{~km}$ northeast. Melitene, an important garrison town and road junction of the eastern frontier of the Roman Empire, was granted city status by Trajan (reigned 98-117 AD) and later served as the capital of Armenia Minor. It was occupied successively by the Persian Sasanids, the Arabs, and the Armenians, and it came under the Seljuq Turks in the $12^{\text {th }}$ century. In 1515 the city was incorporated into the Ottoman Empire under Sultan Selim I. "Malatya, Turkey", Encyclopedia Britannica, Accessed 12 May 2020, https://www.britannica.com/place/Malatya.

6 Ahmed Akgündüz, Said Öztürk and Yaşar Baş, Darende Tarihi (İstanbul: Es-Seyyid Osman Hulusi Efendi Vakfi, 2002), 612 . 
techniques, style and the features of its decorative components, it can be assumed that it was built in the Roman Imperial Period, roughly in the $2^{\text {nd }}$ century AD.

The temple tomb was introduced into the repertoire of the Roman tombs of private individuals, with the first examples under the Flavians and Trajan, with more frequent occurences from the mid-second century onwards. ${ }^{7}$ As each temple tomb had its own unique design, ${ }^{8}$ in Anatolia in the Roman Imperial Period they were mostly used in the Pamphylia, Pisidia, Lycia, Caria and Cilicia regions. ${ }^{9}$ This type of monumental tomb was generally built in politically and socially prosperous periods, which indicates that they were mostly built before the period of economic and social decline usually recognized as occuring in the late third and fourth centuries AD. ${ }^{10}$ In addition to Samosata, Zeugma and Dura Europos; Melitene, now called Eski (Old) Malatya, one of the important passes of the Euphrates River line in the Cappadocia Region ${ }^{11}$, was turned from a simple encampment into a Municipium (city) by Roman Emperor Trajan against the Parthian Empire also in the $2^{\text {nd }}$ century $A D,{ }^{12}$ which coincides with the estimated construction date of the monument. At the time, Darende was also one of the Roman settlements close to the river line. ${ }^{13}$

7 Barbara E. Borg, Roman Tombs and the Art of Commemoration: Contextual Approaches to Funerary Customs in the Second Century CE (Cambridge: Cambridge University Press, 2019), 243.

8 Janos Fedak, Monumental Tombs of the Hellenistic Age (Toronto: University of Toronto Press, 1990), 3-6.

9 Emel Erten, “Olba'daki Tapınak Planlı Anıt Mezar”, Patronvs Coşkun Özgünel'e 65. Yaş Armağanı (İstanbul: Homer Yayınevi, 2007), 149-156.

10 Sarah Cormack, “A Mausoleum at Ariassos, Pisidia”, Anatolian Studies 39 (1989), 31-40;

11 For more information on the Cappadocia Region and Melitene see Thomas A. Sinclair, Eastern Turkey: An Architectural and Archaeological Survey, vol. 1 (London: The Pindar Press, 1987), 83-87 and vol. 2, 506-520; William Mitchell Ramsay, The Historical Geography of Asia Minor (London: John Murray, 1890), 313-314.

12 Yıldırım Ercüment, "Roma-Parth Mücadelesinde Fırat Nehri’nin Jeopolitik Önemi”, Tarihin Peşinde-Uluslararası Tarih ve Sosyal Araştırmalar Dergisi, 7 (2012), 45-64. The ancient cities Samosata, Zeugma and Dura-Europos, established on the west bank of the Euphrates River, are today located respectively in Adiyaman/Samsat (Turkey), Gaziantep/ Belkis Village (Turkey) and near the village of Salhiye (Syria).

13 Akgündüz, Öztürk and Baş, Darende Tarihi, 58-68. 


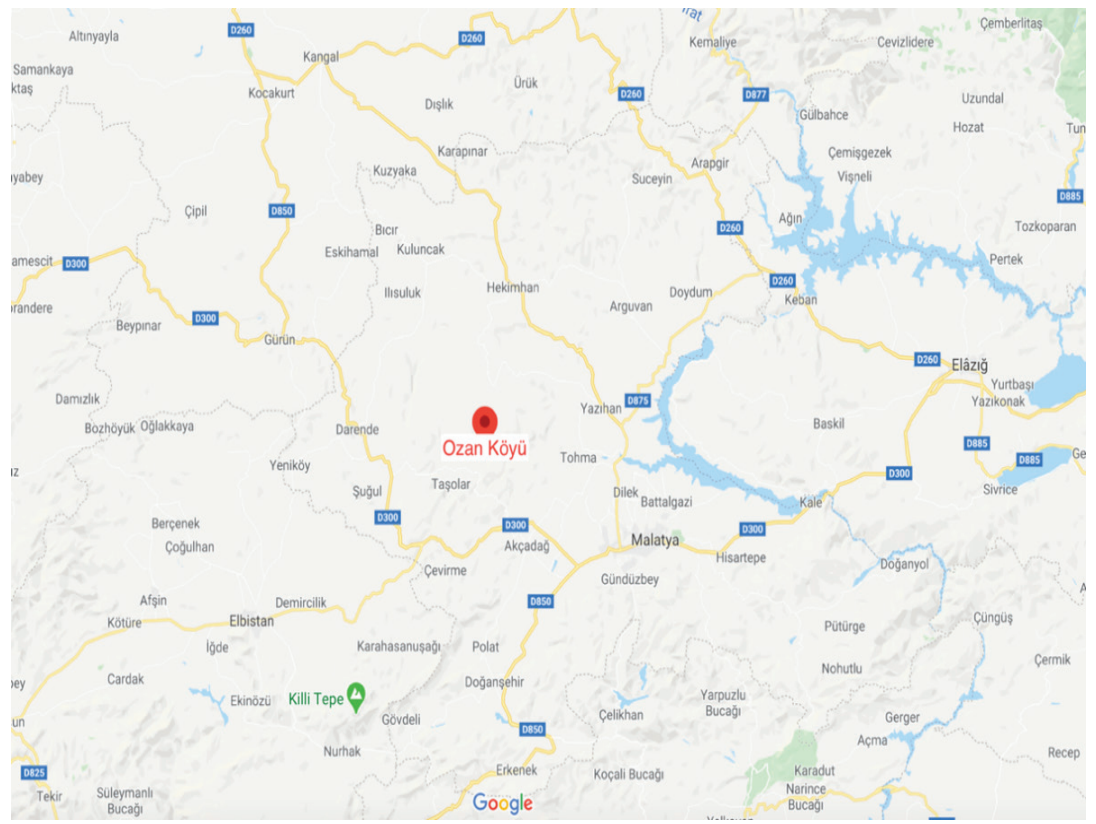

F. 1. The location of the Ozan Village (Ozan Köyü) in Darende, Malatya (Google maps)

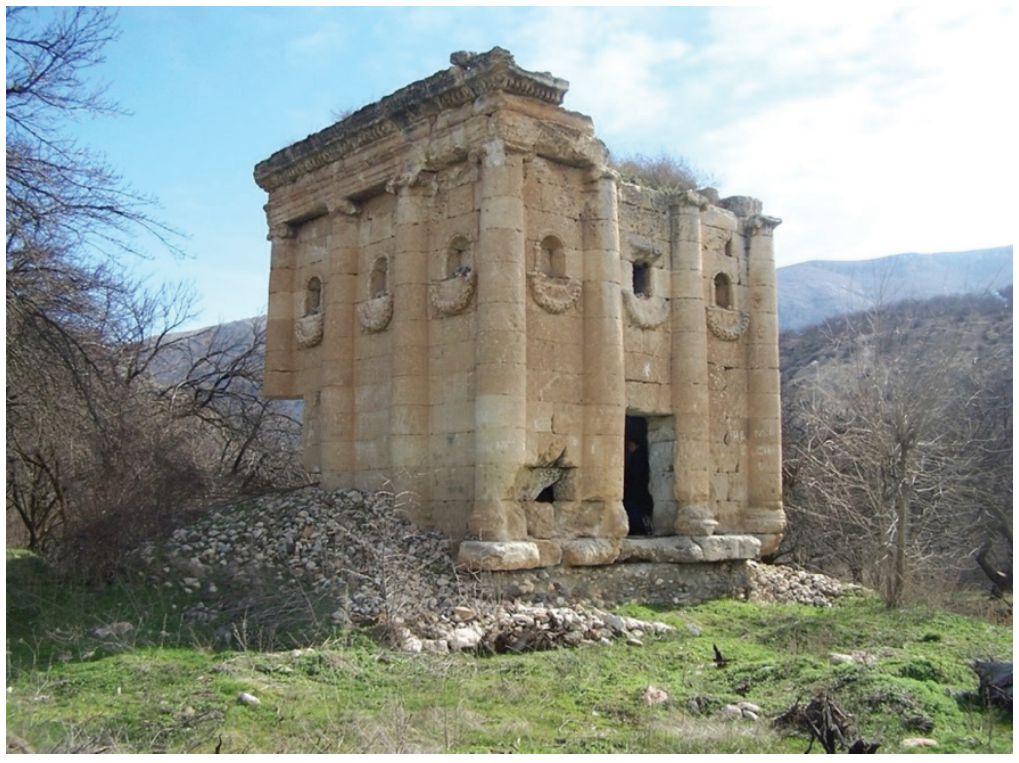

F. 2. West and north facades of the monument (Kemal Kutgün Eyüpgiller, 2018) 


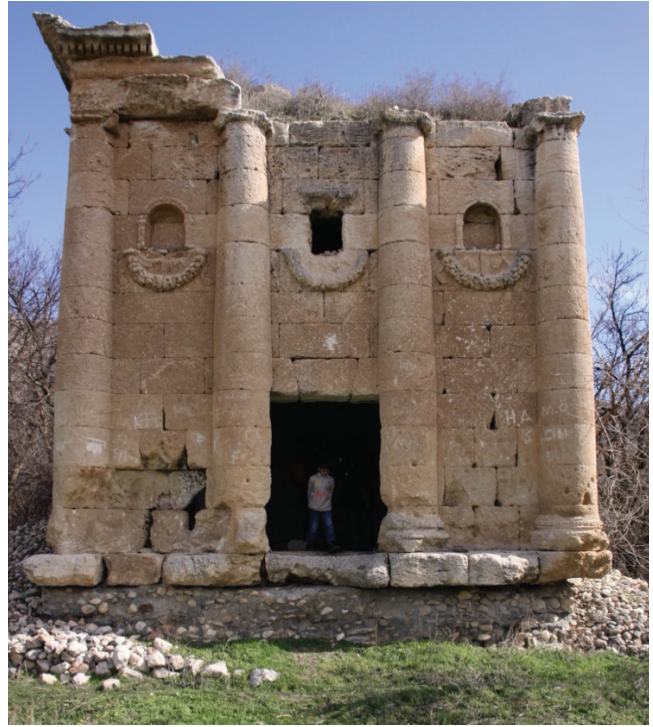

F. 3. West facade of the monument (Kemal Kutgün Eyüpgiller, 2018)

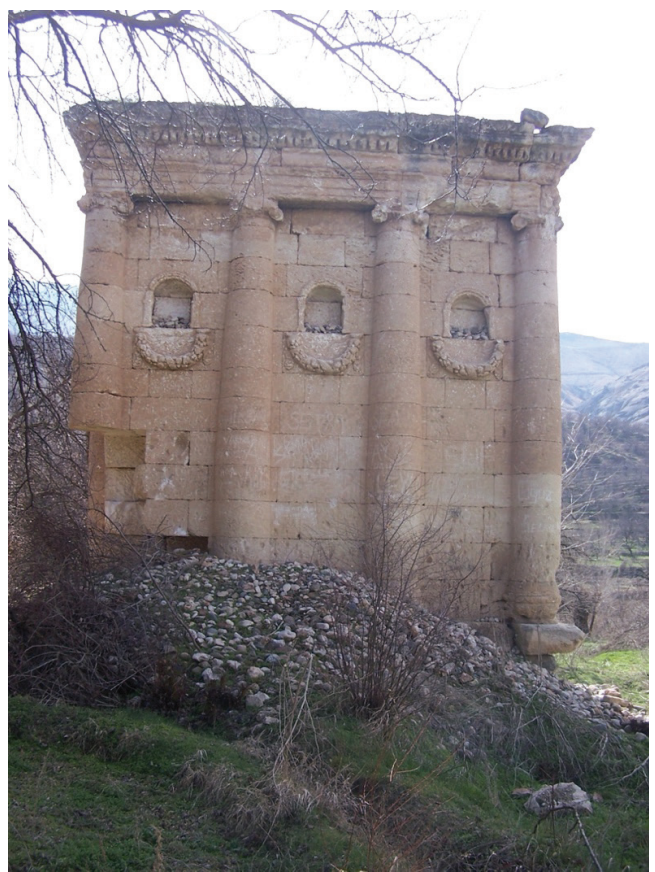

F. 4. North facade of the monument (Kemal Kutgün Eyüpgiller, 2018) 


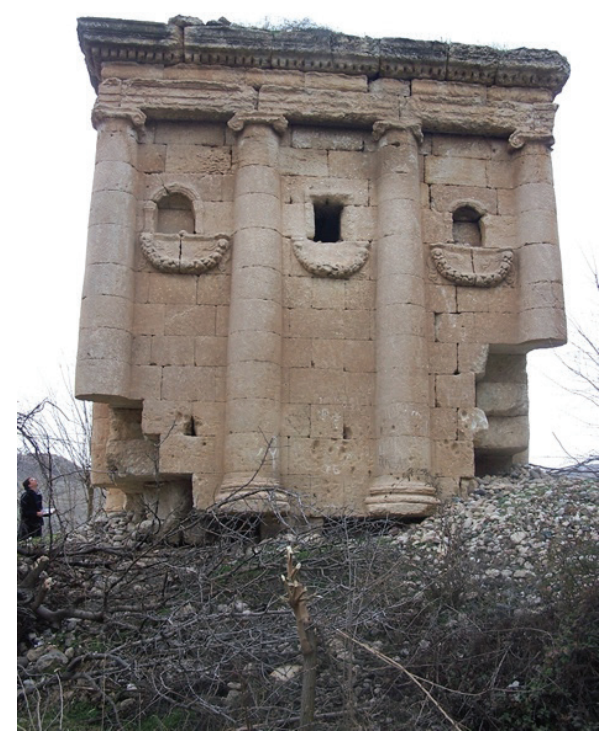

F. 5. East facade of the monument (Kemal Kutgün Eyüpgiller, 2018)

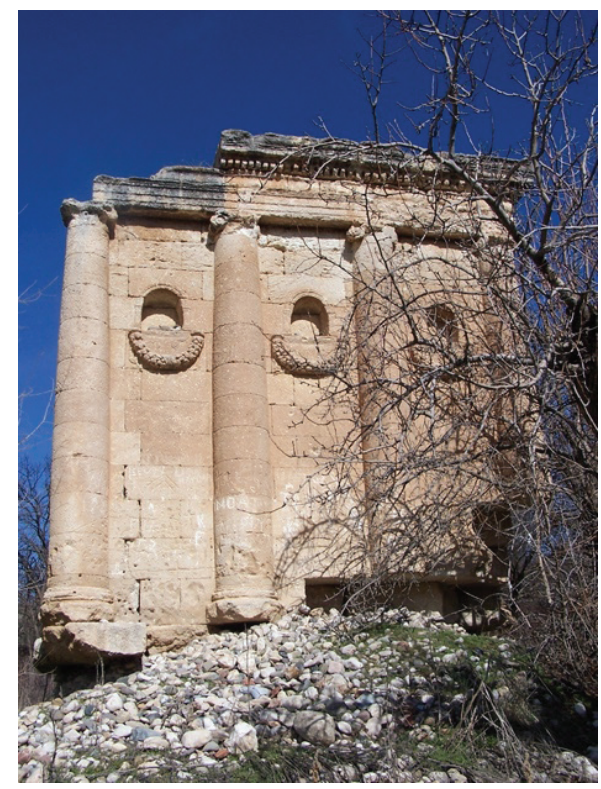

F. 6. South facade of the monument (Kemal Kutgün Eyüpgiller, 2018) 


\section{Architectural Description}

The Ozan Monument is hard to discern in the landscape as it is situated in a vast area covered with apricot gardens. Today the original roofing is lost and covered with a mound of dirt (F. 7). The walls and the interior vault were built with mortar free solid ashlar masonry. The stone used is a derivative of lime stone. The original exterior roofing is assumed to have been built using ashlar masonry just like the walls of the monument. The monument has a square base with four walls of equal length. Since the interior chamber is covered by a barrel vault extending in the east-west direction and supported by the north and south walls, these are thicker than the east and west walls. Therefore, although the monument has a square plan from the outside, it has a rectangular interior plan scheme with a single-chamber.

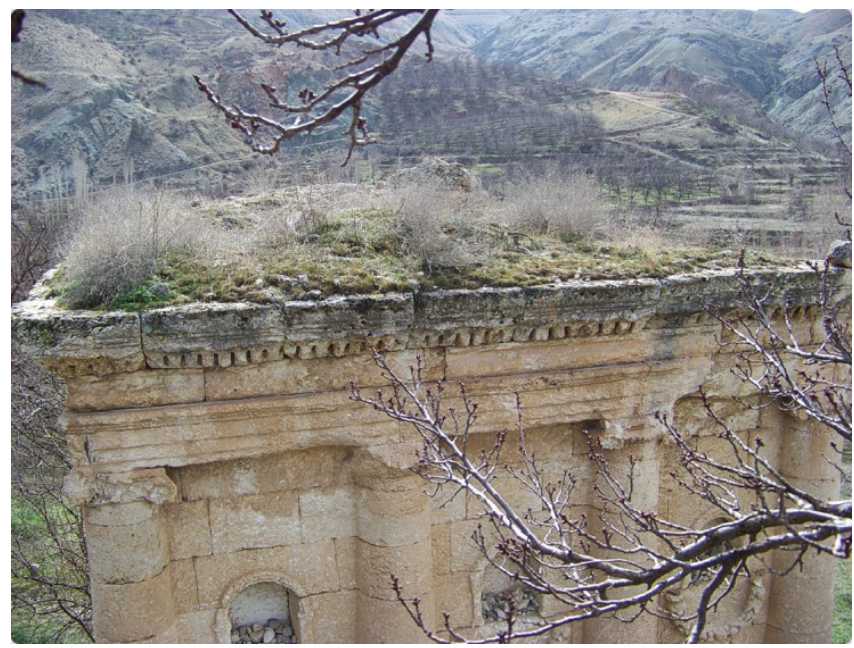

F. 7. Northern view of the roof (Kemal Kutgün Eyüpgiller, 2018)

\section{Plan Characteristics}

The exterior of the monument measures $6.65 \mathrm{~m}$. x $6.65 \mathrm{~m}$. and the interior approximately $3.48 \times 4.5 \mathrm{~m}$. The existing wall thickness on the north and south facades is $125 \mathrm{~cm}$. and approximately $76 \mathrm{~cm}$. on the east and west facades (F. 8, F. 9, F. 10). 


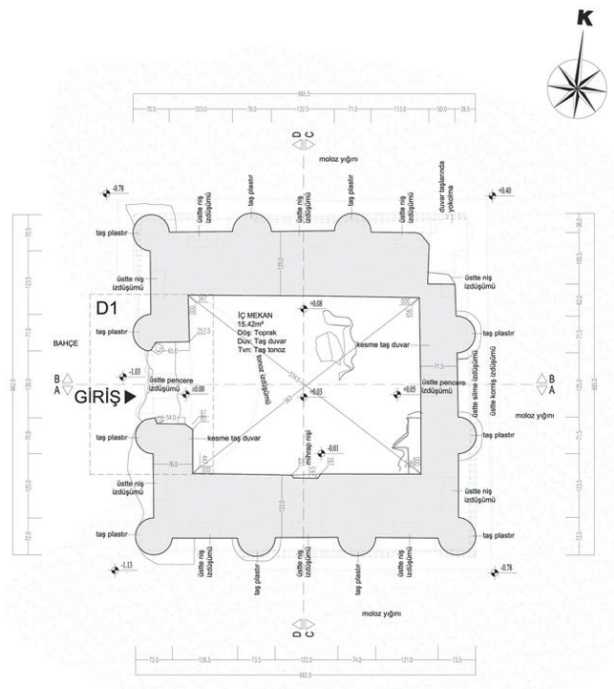

+1.20 KOTU PLANI

F. 8. The survey plan of the monument (Kemal Kutgün Eyüpgiller, 2018) $)^{14}$

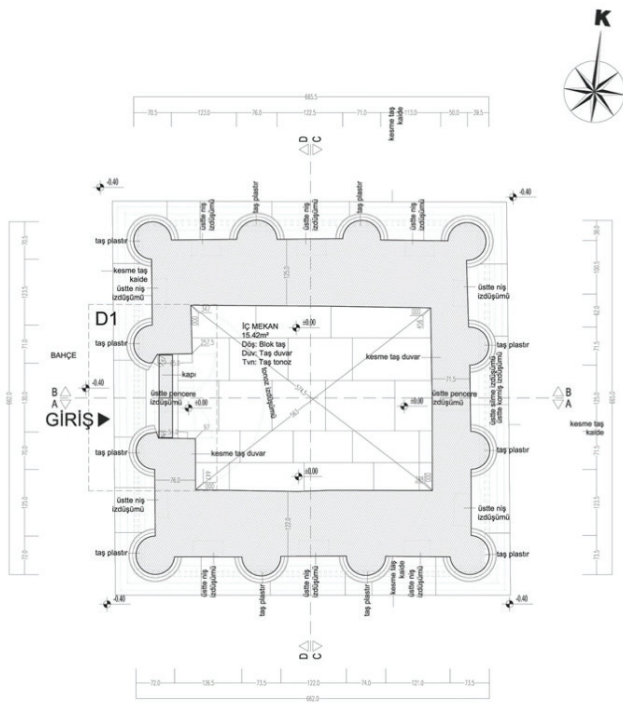

+1.20 KOTU PLANI

F. 9. The restitution plan of the monument (Kemal Kutgün Eyüpgiller, 2018)

14 All of the technical drawings, which are initially published in this article were prepared under the supervision of Prof. Dr. Kemal Kutgün Eyüpgiller. 


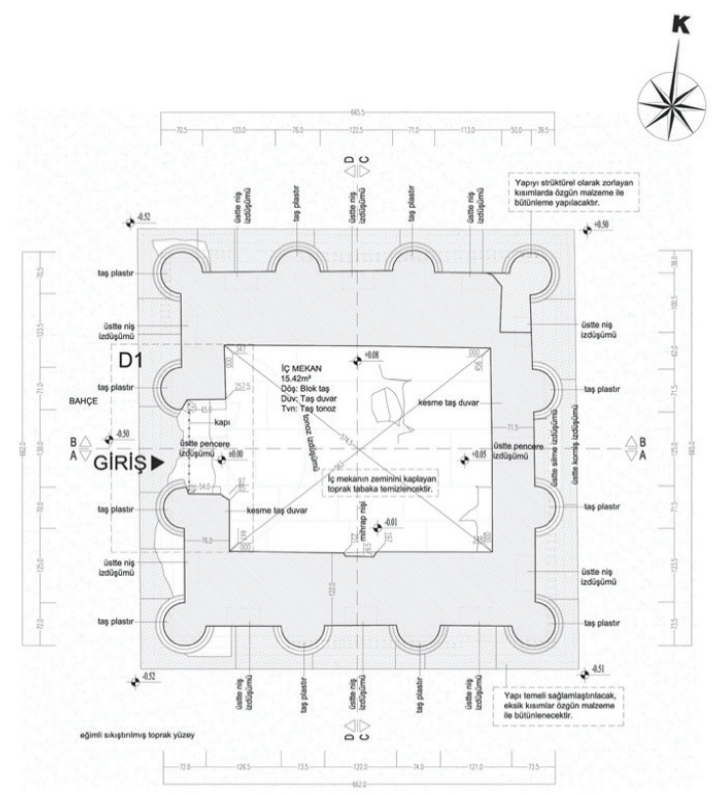

+1.20 KOTU PLANI

F. 10. The restoration plan of the monument (Kemal Kutgün Eyüpgiller, 2018)

The entrance of the monument is at the west facade. There is no portico or a detached pronaos with columns at the entrance facade. ${ }^{15}$ The only openings on the monument are the two single windows placed on the east and west walls at a height of approximately 4 meters and the entrance door on the west wall (F. 11, F. 12). The interior surface of the south wall has been carved out and a mihrab-like niche ${ }^{16}$ placed there later. The ground inside the building is filled with dirt and the original floor covering has largely disappeared. The damaged original stone flooring can be seen only in a small area (F. 13).

15 The Roman temple tomb in Silifke, Mersin and referred to as "Mezgit Kale" and dated to the $2^{\text {nd }}$ century AD just like the Ozan Monument is one of the known examples of a mausoleum with a pronaos in Anatolia.

16 Since this mihrab-like niche is on the south direction, it is likely that it was used as a real mihrab. 


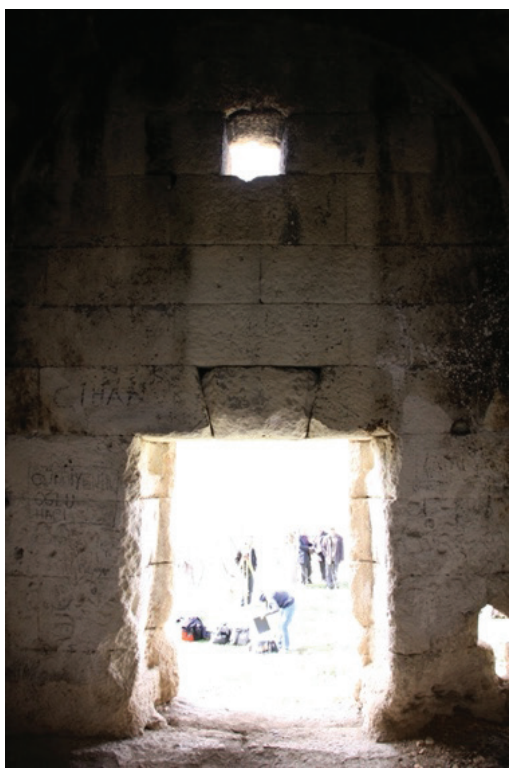

F. 11. The interior surface of the west wall (Kemal Kutgün Eyüpgiller, 2018)

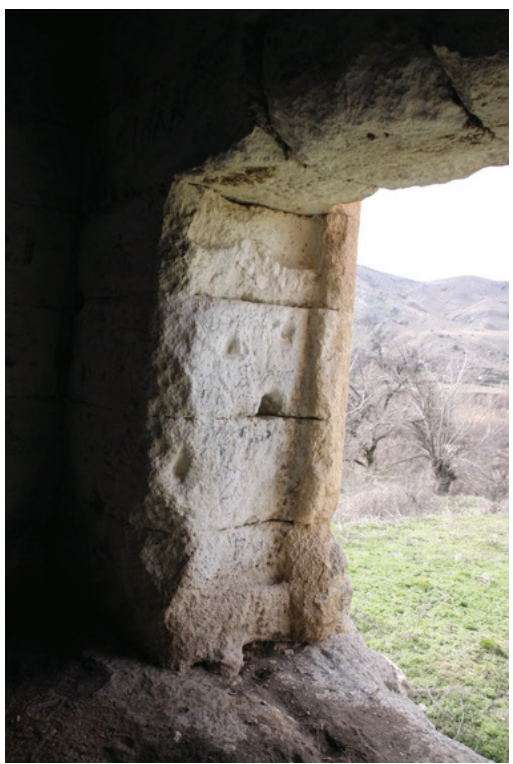

F. 12. The side surface of the entrance (Kemal Kutgün Eyüpgiller, 2018) 


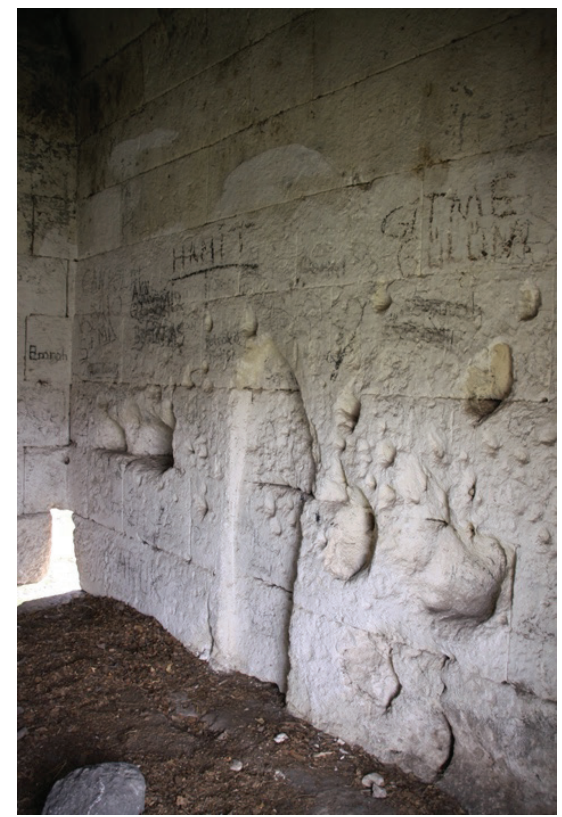

F. 13. The interior surface of the south wall, the mihrab-like niche and the original floor (Kemal Kutgün Eyüpgiller, 2018)

\section{Facadial Features}

One of the earliest examples of an independent temple-like tomb with Greek decoration elements is the Nereid Monument in Xanthos (400-380 BC). This monument has the form of a temple in the Ionic order atop a high, rectangular podium. ${ }^{17}$ In a similar manner, the Ozan Monument was also designed in the form of a temple in the Ionic order. However, unlike the extensive use of the high podium in Roman temples, no podium was used at the Ozan Monument. The total height of the monument from the ground is approximately 6.5 meters. Aside from the wide entrance door on the west wall and the single upper windows on the west and east walls, all of the four facades are identical. On each facade there are four Ionic columns over a base or stylobate with an entablature in the Ionic order above them. The entablature consists of an architrave with three fascias, a flat frieze and a cornice. The columns at the corners are $3 / 4$ columns and those in the middle are half columns (F. 1).

This type of temple, where non-load bearing half columns placed on the facades, were used from the Ancient Greek period onwards and were referred to as pseudoperipteros. In this type the half columns encircling the temple gives the impression

17 William A.P. Childs, Greek Art and Aesthetics in the Fourth Century B.C. (Princeton University: Princeton University Press, 2018), 219. 
that the monument is a peripteros, in other words that the four sides are surrounded by free standing columns. Between the columns there are three small niches symmetrically placed on each facade. These niches are placed four meters from the ground and close to the entablature. The frames of the niches are given an arch form supported by two columns and thick hanging garland reliefs are placed immediately below the niches (F. 15). The central one of these niches on the east and west facades has been opened to serve as a rectangular window (F. 14).

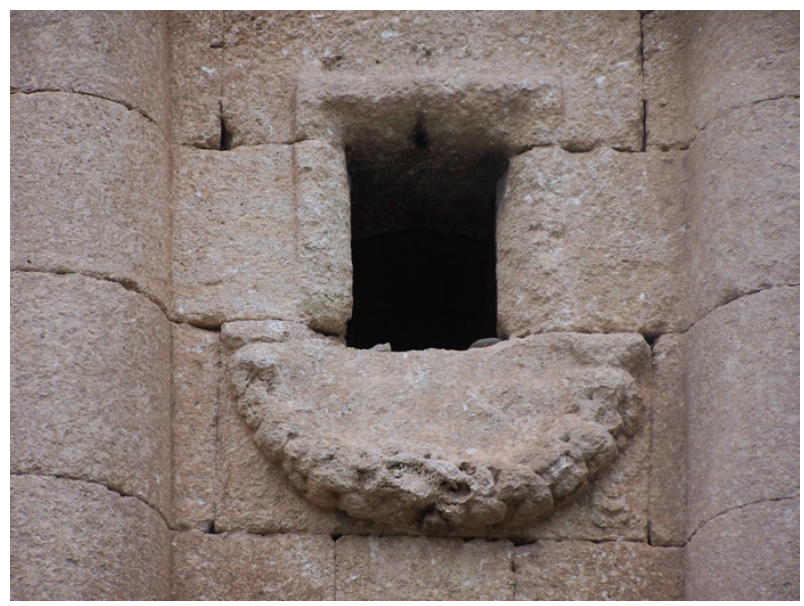

F. 14. The upper window on the east facade (Kemal Kutgün Eyüpgiller, 2018)

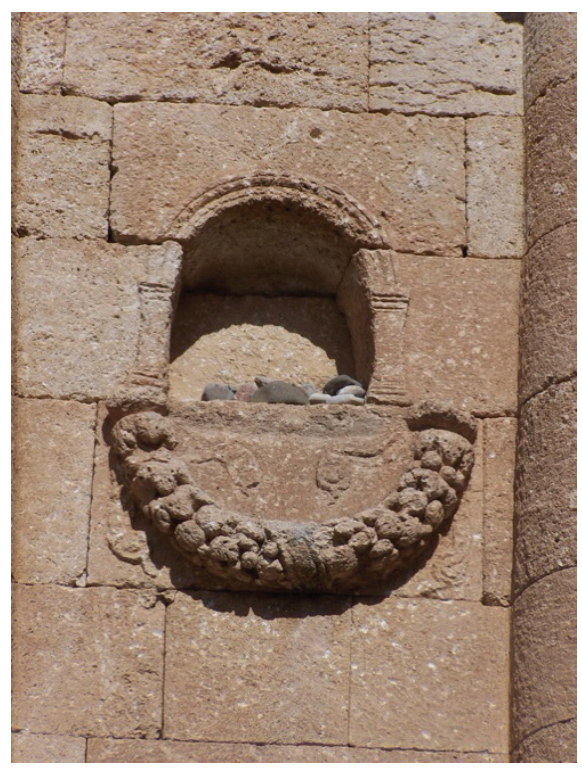

F. 15. One of the niches placed on each facade (Kemal Kutgün Eyüpgiller, 2018) 
In addition to human and animal figures, garlands, i.e. hanging wreathes, were decorative elements frequently used in Roman period mausoleums. There are no written sources explaining their meaning. The said wreathes usually consist of flowers, fruits, laurel oak or ivy leaves and pine cones put together and enlaced by ribbons. ${ }^{18}$ In the Roman Period, the first examples of decorations with garlands are seen in tomb altars and ash urns produced in the $1^{\text {st }}$ and $2^{\text {nd }}$ centuries AD. The sarcophagus with garlands that appeared at the beginning of the $2^{\text {nd }}$ century $\mathrm{AD}$, became popular in the middle of the century and began to lose its popularity towards the end of the century. The sarcophagi found within the boundaries of the Cappadocia Province of the Roman Empire and some of which have garlands are also frequently dated to the end of the $2^{\text {nd }}$ century AD. ${ }^{19}$

Actually, before the Roman Period the garland motif was used to decorate the altars placed on square or circular bases. In these examples, those carrying the garlands were generally the cut head of animals with split hooves such as sheep, cow, goat, roe deer and deer. The earliest garland motifs accurately dated are those found on the Demeter Temple commissioned by Philetairos, the founder of the Pergamon Kingdom. The garlands of the Hellenistic Period are thin, are made only with leaves, do not get thicker in the centre and do not hang down. In contrast, the garlands of the Roman Imperial period get thicker at the centre and hang down. ${ }^{20}$ In the light of this information, we can assume that the garlands of the Ozan Monument are from the Roman period and date roughly to the $2^{\text {nd }}$ century AD. Moreover, the garlands and the niches over them suggest that offerings were devoted to the person for whom the monument was built and that these offerings were placed in these niches.

\section{Damage Assessment}

Overall on the monument there is structural damage and surface deterioration on the stones. The biggest problem of the monument is the ruptures in the corner stones of the facades and the missing stones at the base and the foundation (F. 16, F. 17). The ground level around the monument dropped in the course of time and the foundations were exposed. Due to these faults, the load bearing quality of the structure weakened and some detachments occurred on the main walls. The shortcomings of the monument's roof also make a negative effect on the monument in general. The area between the architrave and the corniche has disappeared in some places. The plant formations on the roof are some of the major damages observed on the exterior mass. The top covering has disappeared to a great extent and it is now in the form of a flat roof (F. 7).

18 Mükerrem Anabolu, "Batı Anadolu'da Bulunan Hellenistik Çağ ve Roma İmparatorluk Çağı Girland Askı(l1) Sunakları", Sanat Tarihi Dergisi 3/3 (1984), 1-17.

19 Koch, Roma Imparatorluk Dönemi Lahitleri, 128, 263.

20 Anabolu, “Batı Anadolu'da Bulunan Hellenistik Çağ ve Roma İmparatorluk Çağı Girland Askı(lı) Sunakları”, 1-17. 
Another example of surface damage observed on the exterior facade is the dirt and abrasion on the limestone cut stones. On average, abrasion on the ashlar masonry is more intense at the +5.00 level. Therefore, almost all the column capitals have lost their decorative details. Moreover, some damage is also observed on the niche decorations depending on the abrasion of the cut stones.

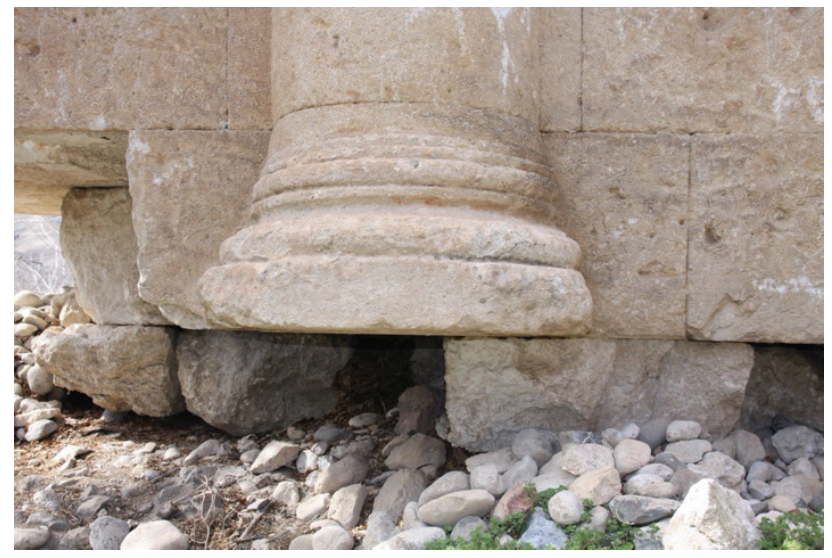

F. 16. One of the column bases (Kemal Kutgün Eyüpgiller, 2018)

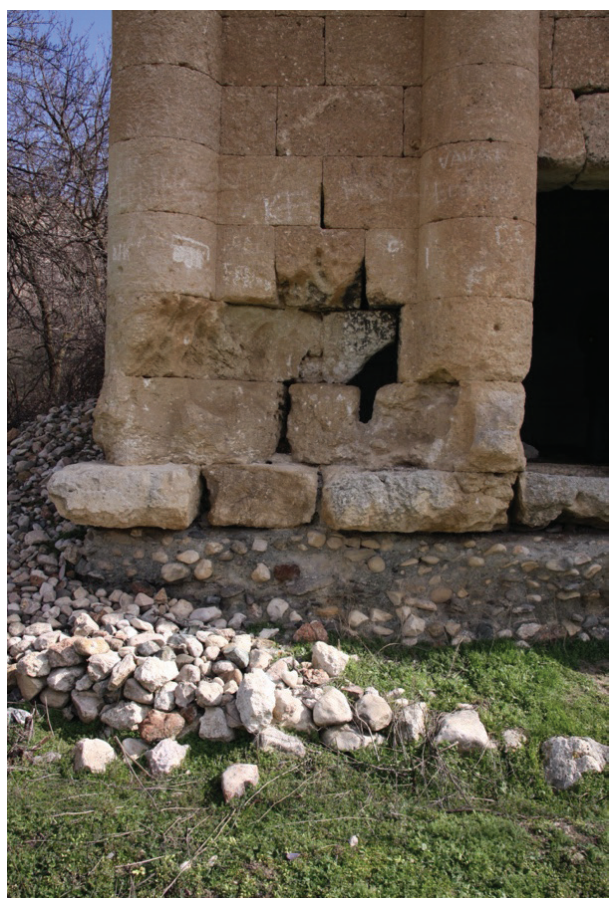

F. 17. The exposed foundation concrete (Kemal Kutgün Eyüpgiller, 2018) 
Just like the great extent of abrasion and surface loss on the west facade, a large portion of the architrave and cornice have disappeared. The plinths of the half columns at the sides of the entrance have also been damaged. On the left lower corner of the north facade, the damage on the building base and the damage on the corner stones have reached a level of total destruction. There is surface loss on all the column capitals and a significant abrasion on the architrave and cornice (F. 18). The most damaged facade of the building is its east facade. Ashlar masonry on both corners of this facade has disappeared. It is observed that the stones of the east wall are partially disconnected from the body of the building. Just like on all the other facades, on the east facade there is a serious abrasion and surface loss on the column capitals and the architrave-cornice aperture. The situation at the south facade is similar to the north facade. In addition to these defects, on the south facade there are also some shortcomings at the right side bottom corner stones and the base of the monument.

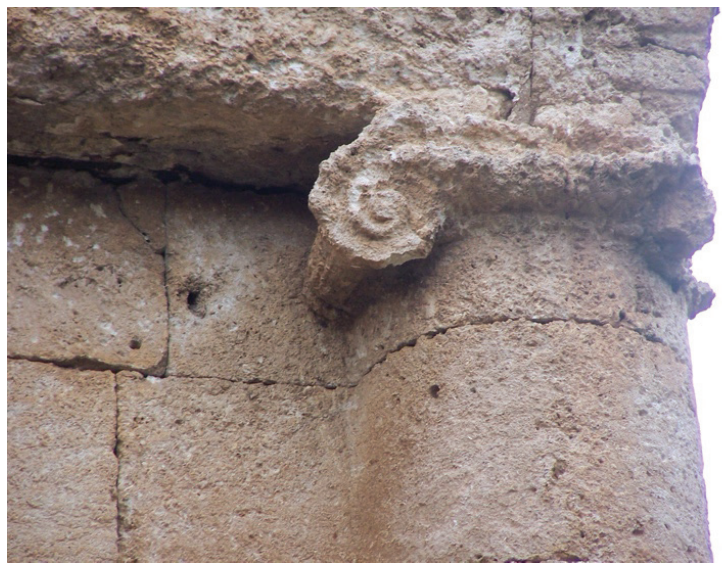

F. 18. Surface loss on the column capitals (Kemal Kutgün Eyüpgiller, 2018)

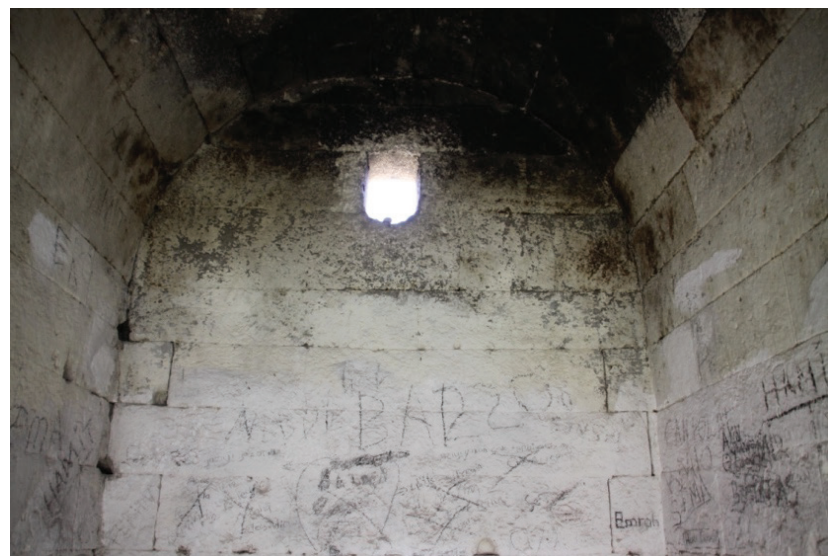

F. 19. The interior surface of the east wall (Kemal Kutgün Eyüpgiller, 2018) 
On the inside of the chamber, the dirt observed on the interior wall surfaces in general is found extensive on the upper level and the upper corners of the west wall (F. 19). Abrasion is observed on the stone surface on both sides of the door opening and there is a hole on the wall on the right side. The key stone over the door opening is slightly dislodged. The ashlar surface on the south wall was hollowed later as a niche similar to a mihrab (F. 13). On the same wall surface there are partial deep cavities and surface abrasion on some of the stones. The east wall is the most damaged wall of the building and the partial disconection of the stones from the monument can also be observed on the interior surface. A hole has emerged on the right corner of the same wall due to the carving of the stone blocks. The problems observed on the north wall of the building are similar to those observed on the south wall. On some of the stones there is abrasion and on some of them there are deep cavities. There is a dense carbon layer/surface deposit on the vault surface starting from the springer level. On some parts of the vault surface humidity and related efflorescence can be observed. The wooden door and window profiles are not found anywhere in the building. The interior floor covering has partially disappeared and partially been covered by dirt filling.

\section{Restitution}

The Ozan Monument has survived to today maintaining its physical integrity to a great extent. The restitution drawings were prepared by analyzing the marks remaining on the building and similar temple tombs of the same period. The said monument figures among the pictures taken by Gertrude Bell who identified numerous historical buildings while touring Anatolia in the early $20^{\text {th }}$ century. ${ }^{21}$ As we can tell from these photos, much of the deterioration observed on the building today was in existence at the time the pictures were taken (F. 20, F. 21, F. 22, F. 23, F. 24).

21 Bell defines the building in her book "Amurath to Amurath" as "Tomb at Ozan" and under a simple scaled plan "Ozan, Tomb". Ishte bu, "said the headman of the village, pointing across the poppy-fields, "here it is;" and he turned away to gather us a dish of ripe mulberries, while I stood in amazement before the Ionic columns and carved garlands of a little tomb that might have graced the Appian Way. There are no inscriptions upon it, nor anything to tell whose bones were laid within the vaulted chamber; I sent a greeting across the ages to the shade of him who had brought into this remote and inaccessible valley the arts of the West, and journeyed on. Gertrude Lowthian Bell, Amurath to Amurath (London: William Heinemann, 1911), 340-341. 


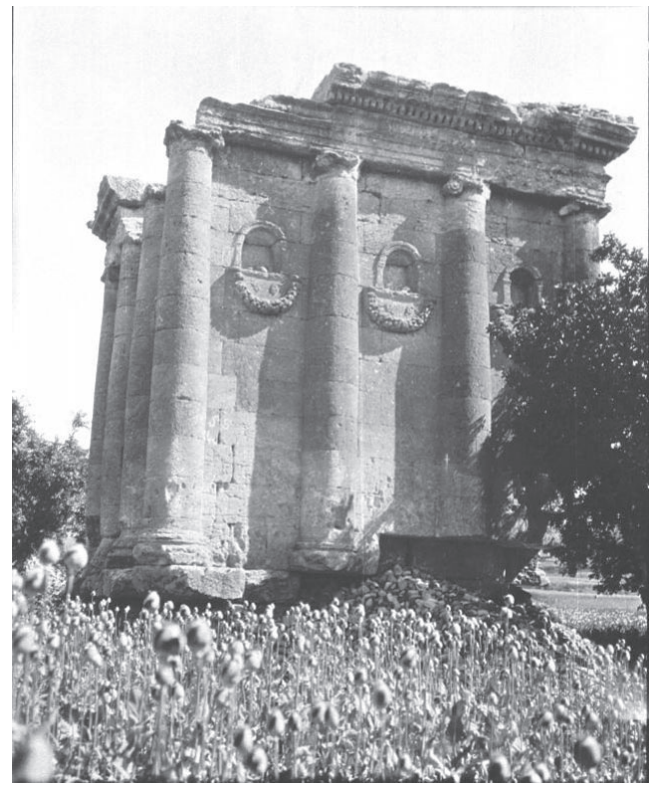

F. 20. The Ozan Monument (Gertrude Bell, 1909), "Album N"

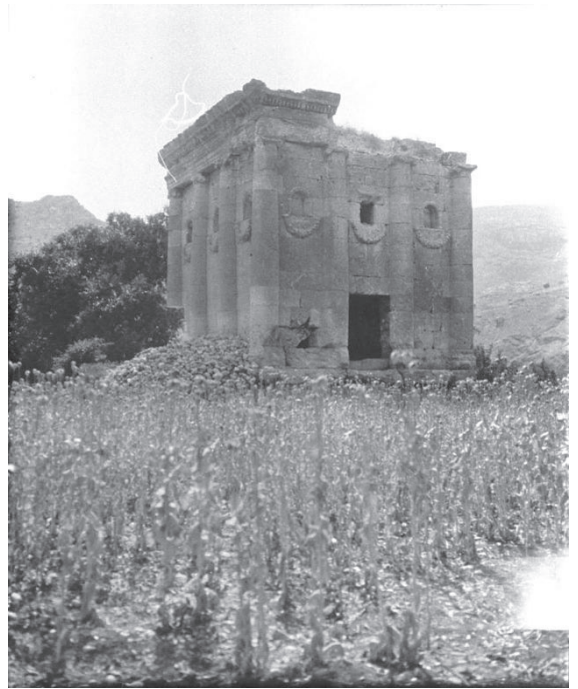

F. 21. The Ozan Monument (Gertrude Bell, 1909), "Album N" 


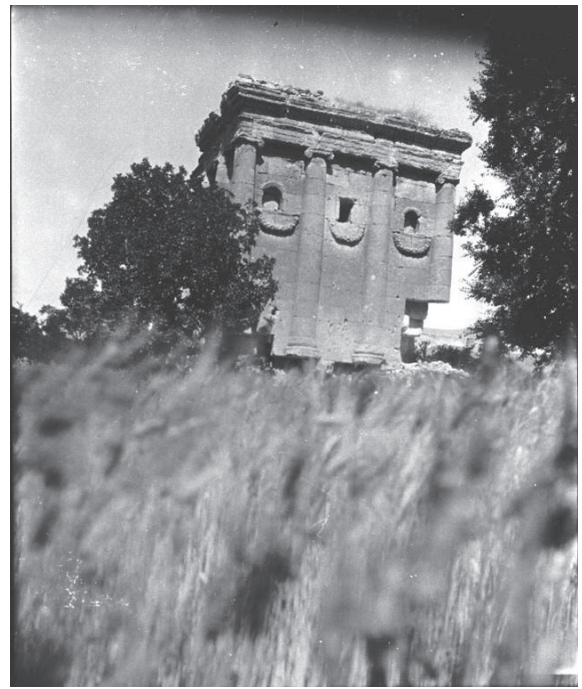

F. 22. The Ozan Monument (Gertrude Bell, 1909), "Album N"

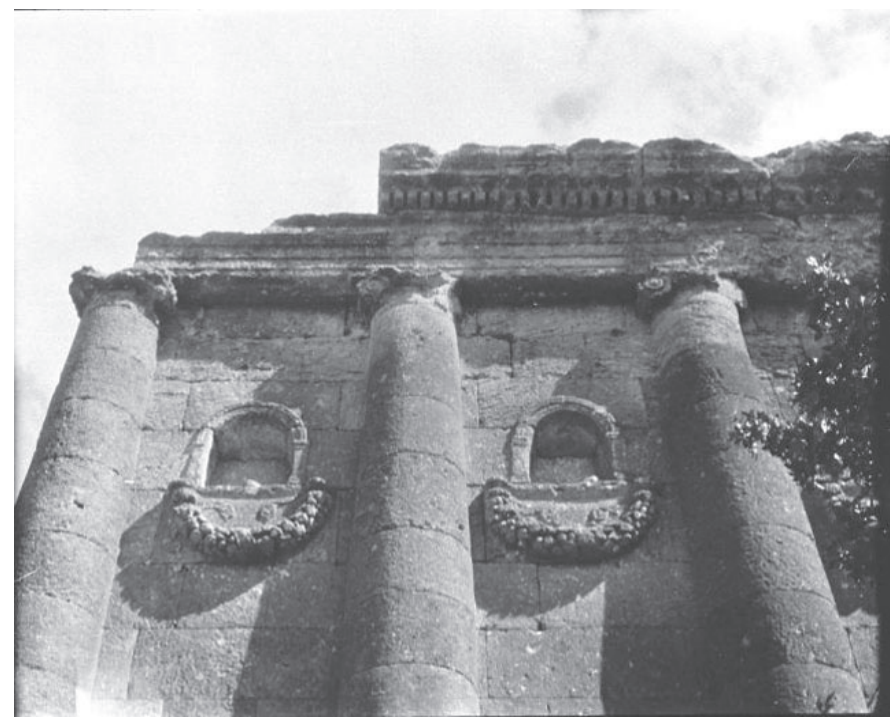

F. 23. The Ozan Monument (Gertrude Bell, 1909), "Album N" 


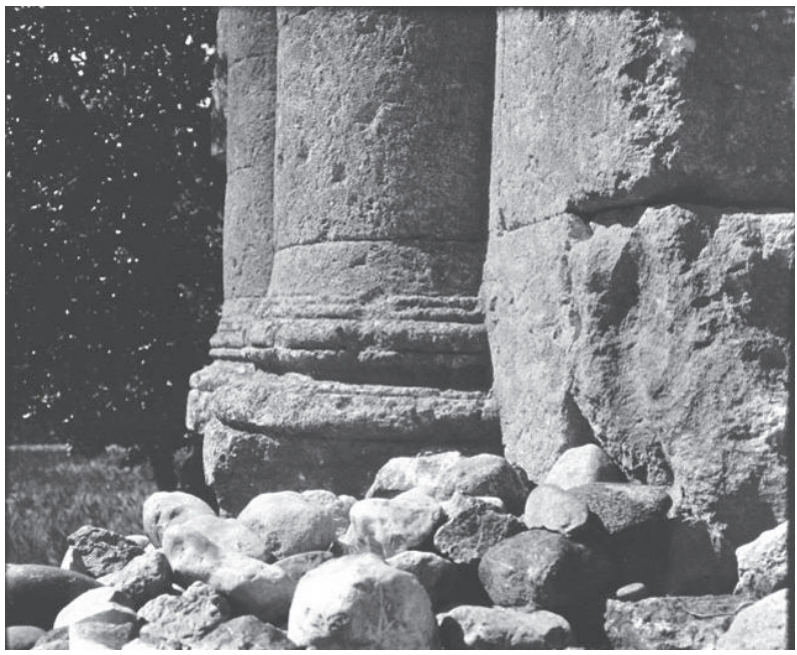

F. 24. The Ozan Monument (Gertrude Bell, 1909), "Album N"

The square layout of the building and the fact that it consists of facades replicating one another have facilitated completing the missing details and ornaments. The large scale missing details and material defects on the facades were completed by analyzing the other identical elements on the building. For example, the corner stones of the east facade were completed based on the other corners. There is abrasion on most of the column capitals. By analyzing each capital individually, the detail marks were collected under one title and the determined original detail was entered into the project. When similar temple tombs in Demircili and Kanlidivane, Mersin were analyzed, it was observed that similar columns to those of the Ozan Monument were used on many of them. ${ }^{22}$

The upper windows on the west and east facades of the Ozan Monument provide ventilation in the chamber. This type of window is also found in similar temple tombs in Demircili and Kanlidivane. ${ }^{23}$

It is considered that there was a saddle roof over the cornice level just like in most of the similar buildings of the period. This roof and its cornice were drawn taking into consideration the Aba Family Tomb Monument of the Olba Kingdom in Kanlidivane, Cilicia. ${ }^{24}$ The roof inclination has been determined as $35 \%$. Based on the form of the

22 "Imbriogion (Demircili)-Mersin", Türkiye Kültür Portalı, accessed 17 October 2019. https://www.kulturportali.gov.tr/turkiye/mersin/gezilecekyer/mbriogion-demircili; "Kanlıdivane", Mersin Gezi, accessed 17 October 2019. https://mersingezi.com/kanlidivane/. For more information on Cilician necropolises and tombs in Mersin see: Alois Machatschek, Die Nekropolen und Grabmäler im Gebiet von Elaiussa Sebaste und Korykos im Rauhen Kilikien (Wien: Böhlau, 1967).

23 Accessed 17 October 2019, https://www.kulturportali.gov.tr/turkiye/mersin/gezilecekyer/mbriogion-demircili; accessed 17 October 2019, https://mersingezi.com/kanlidivane/.

24 Accessed 17 October 2019, https://mersingezi.com/kanlidivane/ 
saddle roof there is a tympanum on the entrance facade. The roof covering has been determined as stone surfacing just like similar buildings of the period (F. 25, F. 26, F. 27, F. 28, F. 29).

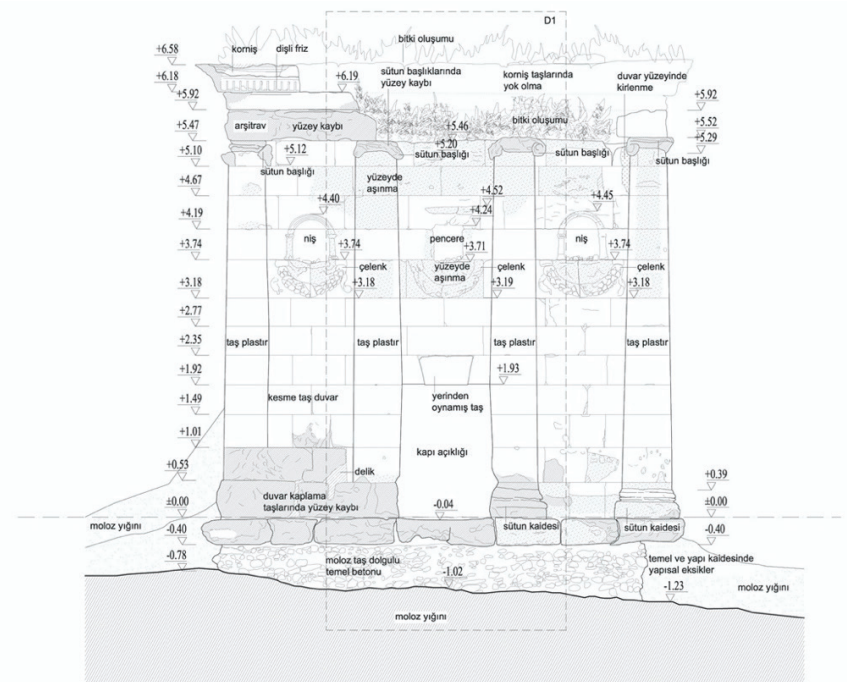

F. 25. The survey drawing of the west facade (Kemal Kutgün Eyüpgiller, 2018)

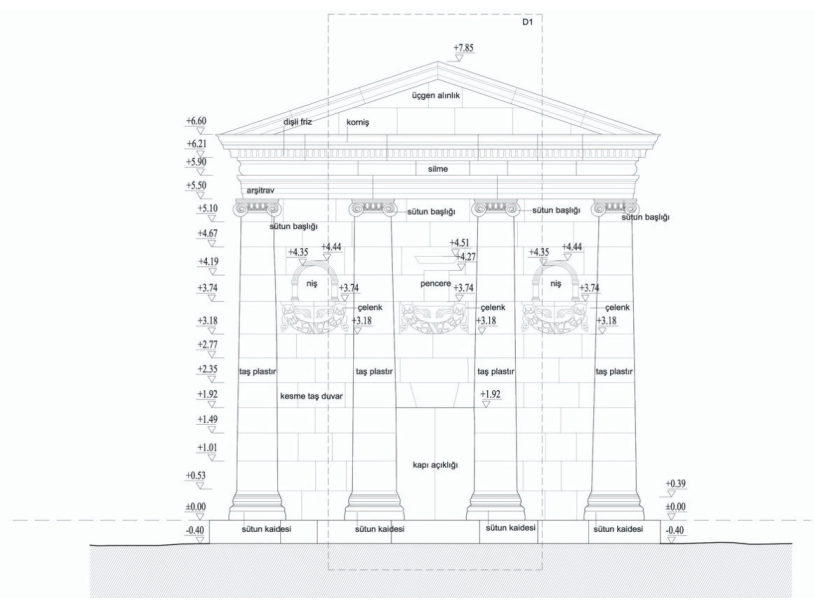

F. 26. The restitution drawing of the west facade (Kemal Kutgün Eyüpgiller, 2018) 


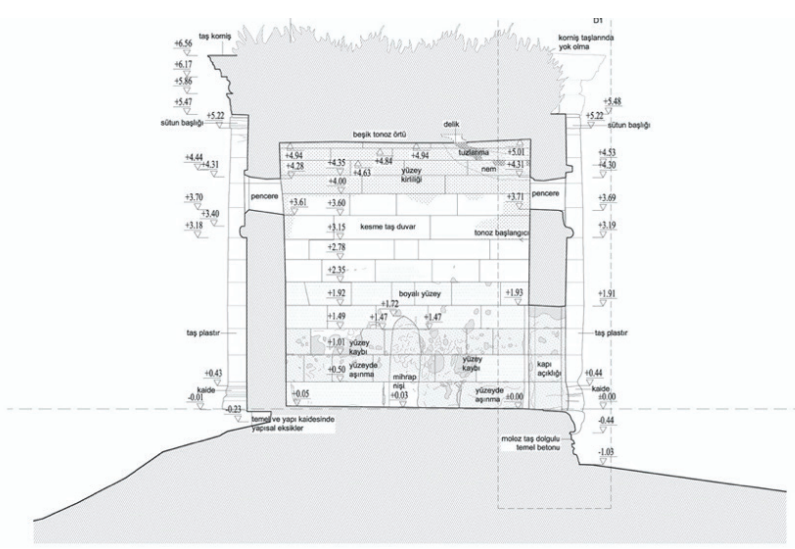

F. 27. The survey drawing of the A-A section (Kemal Kutgün Eyüpgiller, 2018)

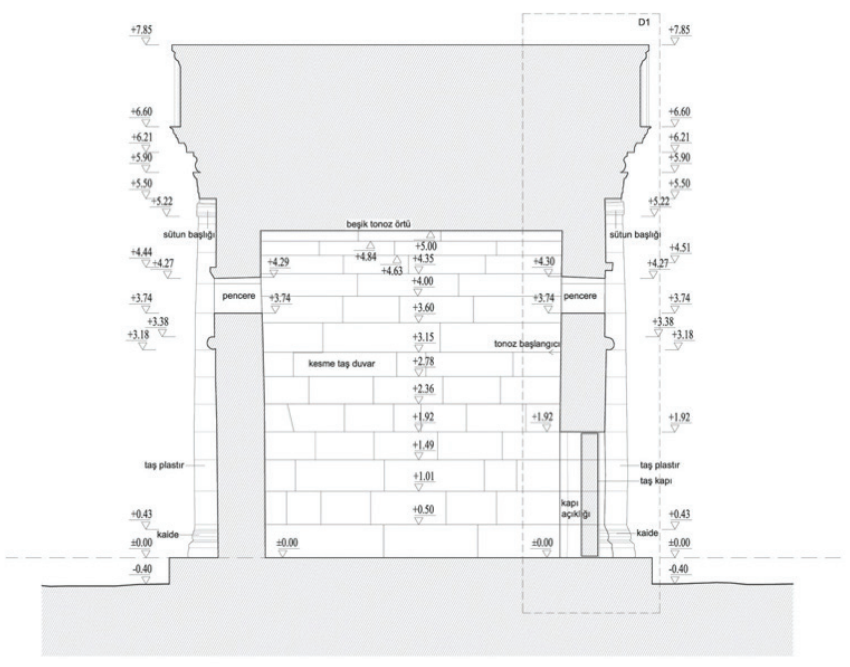

F. 28. The restitution drawing of the A-A section (Kemal Kutgün Eyüpgiller, 2018) 

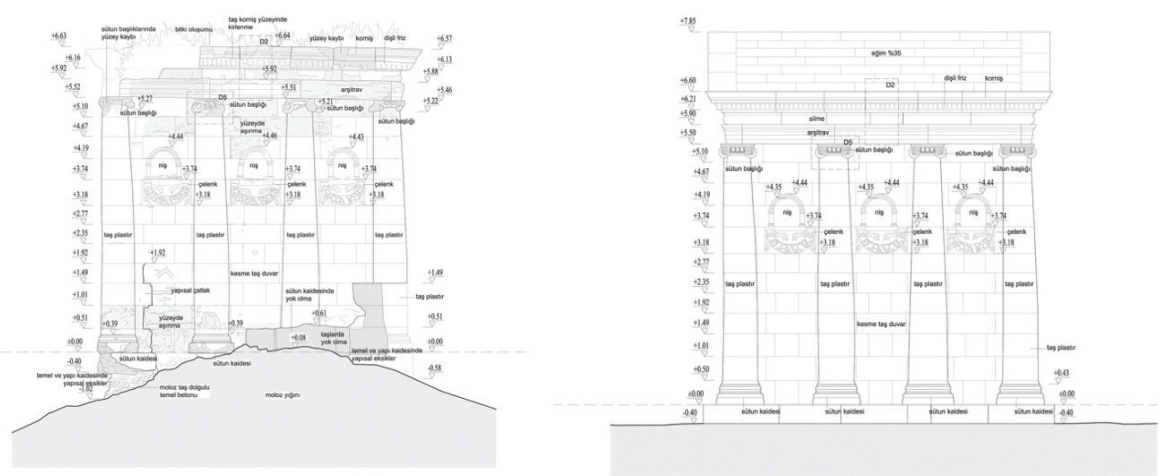

F. 29. The survey and restitution drawings of the south facade (Kemal Kutgün Eyüpgiller, 2018)

Fragments of the building's base that have survived and the exposed rubble-filled foundation concrete have given us an idea regarding the original ground level at the time the monument was built. This level was taken as a base and transferred to the restitution drawings.

Although the entrance opening was eroded to a great extent, it provided enough data about its original state. The entrance with a lintel is also found on the monumental tombs of the same period..$^{25}$ There is no information regarding the wings of the entrance opening. The door wings are not seen in the Gertrude Bell's photographs dated to 1909. In this context, the function of the building and its plain style lead us to assume that the door wings had to be simple, too. A plain door consisting of two stone plates were drawn in the restitution.

\section{Restoration}

The Ozan Monument survived to the present day maintaining many of its original details. The restoration project was to a great extent based on the restitution and the necessary interventions were determined to support the building in the best way possible and carry it to the future. These interventions are listed below:

- Initially the structural strength of the building constructed in the masonry system will be ensured and the problems involving the covering and stability of the walls will be solved.

- The rubble masses around the building will be cleaned without damaging the building, replenishment will be made on the foundation and the base with material compatible with the original (F. 30).

25 Accessed 17 October 2019, https://www.kulturportali.gov.tr/turkiye/mersin/gezilecekyer/mbriogion-demircili; Accessed 17 October 2019, https://mersingezi.com/kanlidivane/. 
- Following consolidation of the foundation, the large ruptures observed on the stone blocks at both corners on the eastern facade of the building will be replenished with the original material in accordance with the project.

- The roof of the building will be initially cleaned. Therefore, the plant layer on the building will be removed using suitable methods and materials. Following this, a protective metal covering will be added in order to curb the water inlet. The roof will have a slope (11\%) which will not be seen from the ground level and the form and material of the roof will not affect the general appearance of the building (F. 30). In the restoration project, it is suggested it is made using a metal covering over a batten system. Rather than a channeled system it is suggested that rain should be allowed to flow freely from a low slope.
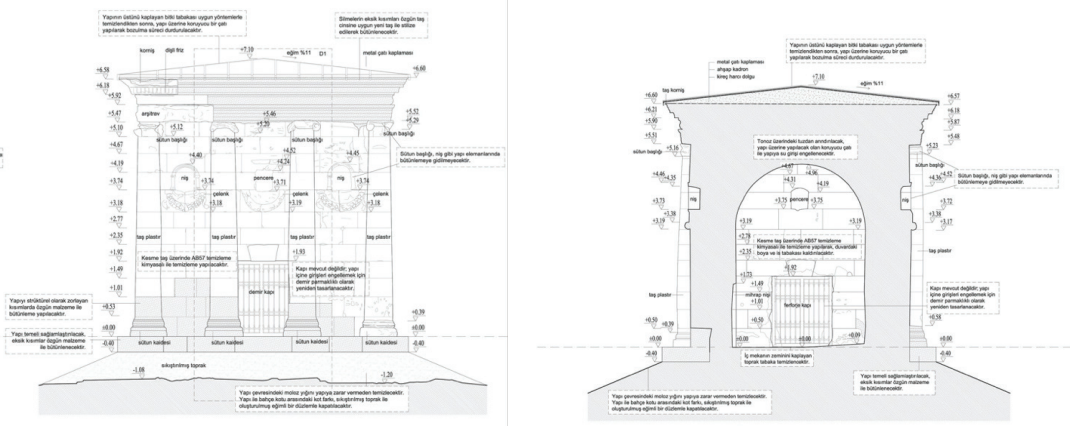

F. 30. The restoration drawings of the west facade and D-D section

(Kemal Kutgün Eyüpgiller, 2018)

- Very careful cleaning will be carried out on ashlar masonry using AB57 and/or ammonium bicarbonate. The dirt under the cornice-moldings will be cleaned.

- No completion will be made in places that do not raise structural difficulties. The defects on the decoration of the column capitals and the niches will be left as is. Completion will be made simplifying the original style only at the missing places of the architrave-cornice part on the building; for example the cornice will be extended as a simple moulding where the dentils have been used.

- The dirt layer covering the interior floor will be cleaned and the original stone floor will be brought out as much as possible. The missing parts of the original foor will be covered with the same kind of limestone.

- No other intervention will be done to the interior walls except for the cleaning of the paint layer on the walls and the carbon layer on the vault. As the mihrap-like niche and the cavities do not affect the statics of the building negatively they will be left as is. 
- The door wings of the building have not survived therefore a door with iron fencing will be made to prevent entry to the monument.

\section{Conclusion}

In the present day there are numerous historical remnants in and around Darende, Malatya, waiting to be researched and to be enlightened with regard to their past. ${ }^{26}$ One of these remnants, the Ozan Monument is an outstanding example of the Anatolian mausolea tradition in the form a Greek temple that has survived to the present day in good condition. This temple tomb in today's Ozan village has been overlooked and no study has yet been carried out on its historical and architectural characteristics. Its size, architectural features, ornaments and comparison with similar temple tombs in Anatolia indicate, that the Ozan Monument was built roughly in the $2^{\text {nd }}$ century $\mathrm{AD}$ in the Roman Imperial Period for a wealthy and high-ranking person of this time. As each mausoleum has its own characteristic design, the Ozan Monument with its unique outlook is one of the significant historical buildings that should be protected in the future. Besides elucidating the history of the monument partially, the main aim of this paper is to introduce this neglected architectural heritage with all of its damage to academic circles and secure its physical existence in the most appropriate and scientific way. To this end, the survey, restitution and restoration projects ${ }^{27}$ of the monument were realized as explained in the paper stey by step and they have been approved by the related conservation region council. As the implementation process is still expected, it is assumed that such an important example of the rich cultural heritage of Anatolia will make a major contribution to the cultural tourism of the region after a meticulous restoration process.

Peer-review: Externally peer-reviewed.

Conflict of Interest: The authors have no conflict of interest to declare.

Grant Support: The authors declared that this study has received no financial support.

Hakem Değerlendirmesi: Dış bağımsız.

Çıkar Çatışması: Yazarlar çıkar çatışması bildirmemiştir.

Finansal Destek: Yazarlar bu çalışma için finansal destek almadığını beyan etmiştir.

\section{References/Kaynakça}

Anabolu, Mükerrem. "Batı Anadolu'da Bulunan Hellenistik Çağ ve Roma İmparatorluk Çağı Girland Askı(11) Sunakları”. Sanat Tarihi Dergisi 3/3 (1984): 1-17.

Akgündüz, Ahmed, Said Öztürk and Yaşar Baş. Darende Tarihi. İstanbul: Es-Seyyid Osman Hulusi Efendi Vakfi, 2002.

26 Akgündüz, Öztürk and Baş, Darende Tarihi, 403.

27 These projects were realized under the guidance of Prof. K. Kutgün Eyüpgiller and completed with the participation of MSc. Architect Tuğba Barlık, MSc. Serda Torus and MSc. Architect Selin Gener Deniz. 
Bell, Gertrude Lowthian. Amurath to Amurath. London: William Heinemann, 1911.

Borg, Barbara E. Roman Tombs and the Art of Commemoration: Contextual Approaches to Funerary Customs in the Second Century CE. Cambridge: Cambridge University Press, 2019.

Childs, William A.P. Greek Art and Aesthetics in the Fourth Century B.C.. Princeton University: Princeton University Press, 2018.

Cormack, Sarah. “A Mausoleum at Ariassos, Pisidia”. Anatolian Studies 39 (1989): 31-40.

Ercüment, Yıldırım. "Roma-Parth Mücadelesinde Fırat Nehri'nin Jeopolitik Önemi”. Tarihin Peşinde-Uluslararası Tarih ve Sosyal Araştırmalar Dergisi 7 (2012): 45-64.

Erten, Emel. “Olba'daki Tapınak Planlı Anıt Mezar”. Patronvs Coşkun Özgünel'e 65. Yaş Armağanı. İstanbul: Homer Yayınevi, 2007, 149-156.

Fedak, Janos. Monumental Tombs of the Hellenistic Age. Toronto: University of Toronto Press, 1990.

Gertrude Bell Archive. “Album N”. Accessed 17 October 2019. http://www.gerty.ncl.ac.uk/

“Imbriogion (Demircili)-Mersin". Türkiye Kültür Portalı. Accessed 17 October 2019. https://www. kulturportali.gov.tr/turkiye/mersin/gezilecekyer/mbriogion-demircili

Jenkins, Ian. "The Mausolea of Halicarnassus". Bulletin of the Institute of Classical Studies 104 (2010): 121-135.

“Kanlıdivane”. Mersin Gezi. Accessed 17 October 2019. https://mersingezi.com/kanlidivane/

Koch, Guntram. Roma Imparatorluk Dönemi Lahitleri. Translated by Z. Zühre İlkgelen. İstanbul: Arkeoloji ve Sanat Yayınları, 2001.

Machatschek, Alois. Die Nekropolen und Grabmäler im Gebiet von Elaiussa Sebaste und Korykos im Rauhen Kilikien. Wien: Böhlau, 1967.

"Malatya, Turkey”. Encyclopedia Britannica. Accessed 12 May 2020. https://www.britannica.com/ place/Malatya

Novakova, Lucia. "Closer to Heaven: The Tradition of Above Ground Burials in Western Anatolia". EYAAIMQN: Studies In Honour of Jan Bouzek. Edited by P. Pavúk, V. Klontza-Jaklová and A. Harding. Prague: Charles University Faculty of Arts, 2018, 179-200.

Novakova, Lucia. "Tombs, Images and Identities in Ancient Anatolia”. ILIRIA International Review 7/2 (2017): 9-20.

Ramsay, William Mitchell. The Historical Geography of Asia Minor. London: John Murray, 1890.

Sinclair, Thomas A. Eastern Turkey: An Architectural and Archaeological Survey. Vol. 1-2. London: The Pindar Press, 1987.

Toynbee, Jocelyn J.M.C. Death and Burial in the Roman World. London: Thames and Hudson, 1996. 